\title{
Perilaku Tes HIV pada Laki-Laki yang Berhubungan Seks dengan Laki-Laki (LSL) di Provinsi Bali
}

\author{
Putu Krisna Saputra*), Antono Suryoputro*), Bagoes Widjanarko*) \\ *Magister Promosi Kesehatan FKM Undip \\ Korespondensi: krisnasaputraputu@gmail.com
}

\begin{abstract}
ABSTRAK
Laki-laki yang berhubungan seks dengan laki-laki (LSL) merupakan populasi yang berisiko tinggi terinfeksi HIV dan AIDS serta Infeksi Menular Seksual (IMS). Berdasarkan data dari Surveilans Terpadu Biologis dan Perilaku (STBP) 2011 ditemukan bahwa prevalensi HIV pada LSL yaitu antara 2,4\%-17\%. Berdasarkan data dari LSM Gaya Dewata, jumlah LSL baru yang dijangkau pada tahun 2013 sebesar 1.322 orang. Namun, jumlah tes HIV yang dilakukan LSL pada tahun 2013 hanya sebesar 874. Sementara angka kasus HIV baru pada LSL tahun 2013 sebesar 118 kasus, jumlah ini meningkat dua kali lipat dari jumlah kasus baru HIV pada LSL tahun 2011 sebesar 50 kasus. Penelitian ini merupakan penelitian kuantitatif dengan rancangan cross sectional. Jumlah sampel sebesar 110 orang yaitu LSL yang telah terjangkau oleh LSM Gaya Dewata di Provinsi Bali. Pemilihan sampel menggunakan teknik purposive sampling. Teknik pengambilan data kuantitatif melalui wawancara dengan kuesioner. Analisis data menggunakan analisis univariat dengan distribusi frekuensi, bivariat menggunakan Chi-Square dan multivariat menggunakan regresi logistik. Hasil penelitian menunjukkan bahwa variabel yang berhubungan dengan perilaku tes HIV pada LSL di Provinsi Bali adalah tipe tempat tinggal dan riwayat IMS. Hasil analisis multivariat menunjukkan bahwa riwayat IMS (p value $=0,005$ ) merupakan variabel yang mempunyai pengaruh paling signifikan terhadap perilaku tes HIV pada LSL di Provinsi Bali dengan OR sebesar 3,400. Perilaku tes HIV pada LSL tergolong baik. Mayoritas responden pernah melakukan tes HIV dalam kurun waktu 0-6 bulan yang lalu. Sebagian besar responden melakukan tes HIV terakhir di Kota Denpasar. Bentuk tes HIV yang dilakukan oleh responden seluruhnya adalah Voluntary Counseling and testing (VCT) serta semua responden mengetahui hasil tes HIV nya.
\end{abstract}

Kata Kunci: LSL, Tes HIV, Bali

\begin{abstract}
Men who have sex with men (MSM) is a high risk population in infected with HIV and AIDS and Sexually Transmitted Infections (STIs) . Based on data from the Integrated Biological and Behavioral Surveillance (IBBS) in 2011 found that HIV prevalence among MSM is between $2.4 \%$ to $17 \%$. Based on data from the Gaya Dewata Foundation, the number of new MSM reached in 2013 amounted to 1,322 people. However, the number of HIV tests among MSM in 2013 only amounted to 874. While the number of new HIV cases among MSM in 2013 amounted to 118 cases, this number increased by two times in 2011, which is amounted to 50 cases. This research is a quantitative study with cross sectional approach. The number of respondents 110 people choosen by purposive sampling technique.Quantitative data collection techniques through interviews with the questionnaire. Data were analyzed using univariate analysis with frequency distribution, using the chi-square bivariate, and multivariate logistic regression. The results showed that the variables associated with HIV testing behavior among MSM in Bali Province is the type of place to stay and history of STIs . Multivariate analysis showed that a history of STIs ( $p$ value $=0.005$ ) is the variable that has the most significant effect on the behavior of HIV testing in MSM in Bali Province with OR of 3.400. HIV testing in MSM behavior quite well. The majority of respondents had an HIV test within 0-6 months ago. Most respondents did last HIV test in Denpasar. Forms of HIV tests performed by the
\end{abstract}


respondent is entirely voluntary counseling and testing ( VCT ) as well as all respondents knew of his HIV test results.

Keywords: MSM, HIV Testing, Bali

\section{PENDAHULUAN}

Kasus HIV dan AIDS di Indonesia telah memasuki level epidemi terkonsentrasi dengan lebih dari 5\% populasi tertentu di beberapa wilayah dan kota di Indonesia terinfeksi HIV. Bahkan di beberapa kota dan wilayah tertentu epidemi ini diperkirakan sudah masuk pada populasi umum. Berdasarkan data dari Surveilans Terpadu Biologis dan Perilaku (STBP) Tahun 2011 ditemukan bahwa prevalensi HIV diantara populasi berisiko yaitu 3,6\%25\% pada Wanita Pekerja Seks (WPS) Langsung, 8,8\% pada Wanita Pekerja Seks (WPS) Tidak Langsung, pada Waria 14$31 \%$, pada laki-laki yang berhubungan seks dengan laki-laki (LSL) 2.4\%-17\%, serta pada pengguna napza suntik (penasun) 25\%-56\% (Kementerian Kesehatan RI, 2011).

Kecenderungan epidemi HIV di masa depan menggambarkan perubahan pola penularan HIV, dimana selain populasi kunci yang sudah ditangani selama ini, penting pula memperhatikan peningkatan infeksi HIV pada LSL (Komisi Penanggulangan AIDS Nasional, 2010). Laki-laki yang berhubungan seks dengan laki-laki merupakan pria yang mengakui dirinya sebagai orang yang biseksual atau homoseksual. LSL cenderung memiliki banyak pasangan seks, baik laki-laki maupun perempuan. Jaringan seksual yang luas ini meningkatkan risiko penularan IMS maupun HIV pada pasangan seksualnya. Jika ada LSL yang tertular IMS atau HIV maupun keduanya sekaligus maka LSL tersebut akan menyebarkan HIV di komunitasnya. Selain itu, LSL yang beristri juga dapat menularkan ke istrinya, perempuan lain, maupun wanita penjaja seks. Jika istrinya tertular HIV, maka ada pula risiko penularan HIV pada bayi yang dikandungnya. Oleh karena itu, LSL dikhawatirkan akan menjadi salah satu mata rantai penyebaran HIV yang potensial (Depkes RI, 2007).

Laki-laki yang berhubungan seks dengan laki-laki merupakan populasi yang berisiko tinggi terkena infeksi Menular Seksual serta HIV dan AIDS. Hal itu disebabkan karena perilaku seksual mereka yang tergolong berisiko misalnya melakukan anal seks tanpa kondom dan pelicin. Epidemi di sebagian besar negara industri terfokus pada LSL, dan penelitian yang dilakukan di Afrika sub-Sahara telah menemukan bukti epidemi HIV yang tinggi di kalangan LSL. Namun, keberadaan kelompok LSL seperti fenomena gunung es, yang berhasil terjangkau hanya bagian kecilnya sementara yang lainnya tetap 
tersembunyi dan tidak mau membuka diri sebagai LSL atau tidak mau mengakui dirinya sebagai LSL (Mumtaz, 2011).

Bali merupakan provinsi yang berada pada urutan kelima dengan jumlah kasus HIV dan AIDS tertinggi di Indonesia, setelah Papua, Jawa Timur, DKI Jakarta, dan Jawa Barat. Berdasarkan statistik kumulatif kasus HIV dan AIDS di Indonesia sampai bulan Juni 2013, angka kasus HIV di Bali mencapai 7.073 kasus, sedangkan angka AIDS mencapai 3.334 kasus (Kemenkes RI, 2013). Proporsi kasus HIV dan AIDS tertinggi berdasarkan kabupaten/kota di provinsi Bali sampai bulan Oktober 2013 terdapat di Kota Denpasar dengan jumlah kasus HIV mencapai 1.644 kasus, sedangkan angka AIDS mencapai 1.708 kasus (Dinkes Provinsi Bali, 2013).

Sampai dengan bulan Oktober 2013, proporsi kasus AIDS pada homoseksual di provinsi Bali mencapai 336 kasus (Dinkes
Provinsi Bali, 2013). Sedangkan angka estimasi untuk jumlah ODHA LSL sebesar 949. Angka estimasi jumlah LSL di provinsi Bali tahun 2012 yaitu 14.098, dimana estimasi LSL tertinggi terdapat di Kota Denpasar yaitu 5.910 (Kemenkes RI, 2012).

Pencegahan infeksi HIV dan AIDS dapat dilakukan dengan pemeriksaan status HIV melalui layanan Voluntary Counseling and Testing (VCT) dan Provider Initiated Testing and Counceling (PITC). Hingga tahun 2011, jumlah layanan tes HIV di Provinsi Bali sebanyak 46 unit yang tersebar di Rumah Sakit Umum maupun swasta dan puskesmas (Dinkes Provinsi Bali, 2013).

Gaya Dewata merupakan Lembaga Swadaya Masyarakat (LSM) yang melakukan penjangkauan pada LSL di wilayah jangkauan yaitu, kota Denpasar, Kabupaten Badung, dan Kabupaten Gianyar. 
Tabel 1 Jumlah LSL yang telah dijangkau, jumlah tes HIV, dan Jumlah HIV Positif di tahun 2011-2013

\begin{tabular}{|c|c|c|c|c|}
\hline Tahun & Kabupaten/Kota & LSL Dijangkau & Tes HIV & HIV Positif \\
\hline \multirow[t]{3}{*}{2011} & Denpasar & 730 & 237 & 25 \\
\hline & Badung & 625 & 133 & 25 \\
\hline & Gianyar & 43 & 13 & 0 \\
\hline \multicolumn{2}{|l|}{ Jumlah } & 1.390 & 383 & 50 \\
\hline \multirow[t]{3}{*}{2012} & Denpasar & 669 & 482 & 65 \\
\hline & Badung & 455 & 297 & 33 \\
\hline & Gianyar & 50 & 10 & 6 \\
\hline \multicolumn{2}{|c|}{ Jumlah } & 1.174 & 789 & 104 \\
\hline \multirow[t]{3}{*}{2013} & Denpasar & 745 & 533 & 71 \\
\hline & Badung & 497 & 321 & 40 \\
\hline & Gianyar & 80 & 20 & 7 \\
\hline \multicolumn{2}{|l|}{ Jumlah } & 1.322 & 874 & 118 \\
\hline \multicolumn{2}{|l|}{ Total } & 3.886 & & \\
\hline
\end{tabular}

Sumber: Yayasan Gaya Dewata, 2011;2012;2013

Berdasarkan data di atas, dapat disimpulkan bahwa jumlah penjangkauan tiap tahunnya lebih banyak dibanding dengan jumlah tes HIV. Tahun 2011, jumlah tes HIV hanya $27,55 \%$ dari jumlah penjangkauan. Tahun 2012, jumlah tes HIV sebanyak $67,2 \%$ dari jumlah penjangkauan dan tahun 2013 jumlah tes HIV sebanyak $66,11 \%$ dari jumlah penjanguan. Dari data di atas juga dapat diketahui bahwa jumlah kasus positif HIV semakin meningkat dari tahun 2011-2013, tahun 2013 jumlah positif HIV meningkat dua kali dari jumlah kasus HIV positif tahun 2011.

Tes HIV merupakan hal yang penting untuk dilakukan oleh populasi kunci, dalam hal ini yaitu LSL. Namun, masih terdapat beberapa faktor yang membatasi akses LSL terhadap informasi dan berbagai layanan tersebut. Faktor tersebut meliputi pengetahuan, persepsi masyarakat terhadap komunitas LSL maupun isu HIV dan AIDS, stigma, perilaku seksual, keberadaan penjangkau, strategi penjangkauan, serta kecemasan akan hasil tes HIV (Lestari, 2012; Bwambale, 2008; Wang, 2011). Terkait dengan stigma dan diskriminasi, secara tidak langsung menimbulkan ketidakseimbangan dalam pengembangan informasi dan layanan bagi LSL. Di lain pihak, internalisasi stigma oleh LSL dan banyaknya tantangan untuk mengakses program yang ada, mengakibatkan populasi ini sering enggan bahkan tidak mau mengakses dan memanfaatkan informasi serta layanan yang tersedia (Komisi Penanggulangan AIDS Nasional, 2010).

Berdasarkan uraian di atas, peneliti tertarik untuk menganalisis perilaku tes HIV pada LSL di Provinsi Bali. 


\section{METODE}

Penelitian ini merupakan penelitian kuantitatif dengan rancangan cross sectional. Jumlah sampel sebesar 110 orang yaitu LSL yang telah terjangkau oleh LSM Gaya Dewata di Provinsi Bali. Pemilihan sampel menggunakan teknik purposive sampling. Teknik pengambilan data kuantitatif melalui wawancara dengan kuesioner. Analisis data menggunakan analisis univariat dengan distribusi frekuensi, bivariat menggunakan ChiSquare dan multivariat menggunakan regresi logistik.

\section{HASIL DAN PEMBAHASAN}

\section{Perilaku Tes HIV pada LSL}

Mayoritas responden sebanyak
$51,8 \%$ memiliki perilaku tes HIV yang tergolong baik, yaitu melakukan tes HIV secara berulang dan terakhir melakukan tes HIV dalam rentang waktu 0-6 bulan yang lalu. Sedangkan sisanya sebesar 48,2\% memiliki perilaku tes HIV yang tergolong buruk, yaitu tidak pernah melakukan tes HIV atau terakhir melakukan tes HIV dalam kurun waktu lebih dari 6 bulan yang lalu Berdasarkan lokasi tes HIV, sebagian besar responden melakukan tes HIV terakhir di Kota Denpasar (56,7\%), sedangkan 36,7\% responden melakukan tes HIV terakhir di Kabupaten Badung, 3,3\% responden melakukan tes di kabupaten Gianyar, dan $3,3 \%$ responden melakukan tes di luar
Provinsi Bali. Dari semua responden yang pernah melakukan tes HIV, seluruhnya (100\%) melakukan tes HIV berupa Voluntary Counseling and testing (VCT) dan seluruhnya mengetahui hasil tes tersebut.

Faktor yang memiliki hubungan yang signifikan secara statistik terhadap perilaku tes HIV yaitu: jenis tempat tinggal dan riwayat IMS. Riwayat IMS merupakan variabel yang paling berpengaruh terhadap perilaku tes HIV pada LSL di Provinsi Bali. Responden dengan riwayat IMS tergolong berisiko tinggi cenderung 3,4 kali lebih besar untuk melakukan tes HIV dibandingkan dengan responden dengan riwayat IMS tergolong berisiko rendah.

Berdasarkan hasil penelitian, sebanyak $48,2 \%$ responden tergolong memiliki perilaku tes HIV yang buruk. Beberapa alasan responden belum pernah melakukan tes HIV adalah mereka tidak merasa melakukan perilaku berisiko HIV karena merasa setia pada pasangan. Selain itu, beberapa responden juga merasa belum siap menerima hasil tes HIV, karena nanti jika hasilnya positif (reaktif) mereka akan merasa stress.

Menurut teori Health Belief Model yang dikembangkan oleh Rosenstock, perubahan perilaku dapat terjadi jika terdapat tiga faktor yang berhubungan dengan perilaku kesehatan. Pertama, seorang individu harus merasa terancam 
oleh perilakunya saat ini. Kedua, seorang indiviidu harus memiliki kepercayaan bahwa perubahan perilaku tersebut akan mendatangkan manfaat bagi dirinya. Ketiga, individu harus merasa bahwa dia dapat melaksanakan perubahan perilaku tersebut (Walker, 2004). Terkait hasil penelitian ini, responden yang tergolong memiliki perilaku tes HIV yang buruk tidak merasa memiliki perilaku berisiko, sehingga tidak merasa terancam oleh perilakunya. Di samping itu, jika nanti melakukan tes HIV dan hasilnya positif (reaktif), responden tidak merasakan manfaat bagi dirinya, bahkan responden akan menjadi stress.

Menurut pedoman Kemenkes RI, LSL termasuk ke dalam kategori populasi berisiko tinggi tertular HIV. Hal ini karena perilaku seksual mereka yang sering berganti-ganti pasangan. Untuk itu dihimbau untuk mengulangi tes HIV secara berkala minimal tiga bulan setelah melakukan aktivitas seksual berisiko HIV. Hal ini karena sebelum tiga bulan, tes antibodi akan menunjukkan hasil negatif (non reaktif), tetapi sudah dapat menularkan virus ke orang lain. Fase ini disebut masa jendela (Yayasan Spiritia, 2013).

Lokasi tes HIV yang dilakukan responden sebagian besar $(56,7 \%)$ adalah di Kota Denpasar. hal ini karena Denpasar merupakan pusat Kota, sehingga fasilitas tes HIV pun lebih banyak. Di Kota
Denpasar terdapat 4 Puskesmas yang telah dilatih untuk ramah Gay, Waria, dan LSL (GWL) yaitu: puskesmas 1 Denpasar Timur, Puskesmas 2 Denpasar Selatan, Puskesmas 2 Denpasar Barat, dan Puskesmas 2 Denpasar Utara. Selain itu, beberapa rumah sakit dan klinik swasta yang melayani tes HIV juga terdapat di Kota Denpasar. para penjangkau lapangan di Yayasan gaya Dewata juga lebih banyak merujuk LSL jangkauannya untuk melakukan tes HIV di Kota Denpasar karena aksesnya lebih mudah dan LSL juga lebih banyak menjalankan kesehariannya di Kota Denpasar.

Bentuk tes HIV yang dilakukan responden adalah VCT dan seluruh responden mengetahui hasil tesnya. VCT merupakan tes HIV sukarela. Semua responden dalam penelitian ini terlihat sehat, sehingga mereka melakukan tes HIV berupa VCT, bukan PITC (Provider Initiative Testing and Counseling). Prosedur VCT pun sudah dilaksanakan oleh responden, mulai dari konseling pra tes hingga pembacaan hasil tes. Ketika diwawancara, semua responden dalam penelitian ini menyatakan status HIVnya non reaktif (negatif).

\section{Karakteristik Responden Menurut} Umur

Berdasarkan hasil penelitian statistik univariat menunjukkan bahwa 
umur responden sebagian besar dalam kategori umur dewasa (>24 tahun) yaitu sebesar $61,8 \%$, sedangkan kategori umur remaja ( $\leq 24$ tahun) sebesar $38,2 \%$. Umur responden yang paling muda adalah 19 tahun, sedangkan umur responden yang paling tua adalah 49 tahun.

Hasil analisis bivariat menunjukkan bahwa uji statistik dengan chi-square diperoleh $\mathrm{p}$ value 0,772 dimana $\mathrm{p} \geq 0,05$ sehingga secara statistik tidak signifikan maka dapat diketahui bahwa tidak terdapat hubungan antara umur responden dengan perilaku tes HIV. Dari hasil tabulasi silang menunjukkan bahwa responden yang memiliki perilaku tes HIV tergolong baik lebih banyak terdapat pada responden dengan kategori umur remaja $(54,8 \%)$ dibandingkan dengan responden dengan kategori umur dewasa (50,0\%). Sedangkan responden yang memiliki perilaku tes HIV tergolong buruk lebih banyak terdapat pada responden dengan kategori umur dewasa (50,0\%) dibandingkan dengan responden dengan kategori umur remaja (45,2\%).

Hubungan antara umur dengan pemanfaatan pelayanan kesehatan umumnya digambarkan dengan kurve U. Kelompok umur sangat muda dan kelompok umur sangat tua merupakan kelompok umur yang paling banyak memanfaatkan pelayanan kesehatan karena dihubungkan dengan morbiditas. Umur yang semakin matang akan mempengaruhi dalam pemikiran untuk perlindungan diri terutama masalah kesehatan (Andersen, 1995). Namun, dalam penelitian ini, responden yang memiliki perilaku tes HIV tergolong baik yaitu responden dengan kategori umur remaja. Berdasarkan kondisi di lapangan, penjangkau lapangan juga menggunakan sarana sosial media internet untuk menjangkau LSL. Sebagian besar pengguna sosial media tersebut tergolong ke dalam kelompok usia remaja. Banyak LSL usia remaja yang terpapar mengenai informasi tes HIV baik melalui internet maupun acara kumpul-kumpul sesama LSL sehingga mereka banyak yang memiliki perilaku tes HIV tergolong baik. Sedangkan responden kelompok umur dewasa jarang memiliki waktu untuk berkumpul dengan sesama reka LSL karena sibuk bekerja.

\section{Karakteristik Responden Menurut Tingkat Pendidikan}

Berdasarkan hasil penelitian statistik univariat menunjukkan bahwa tingkat pendidikan responden sebagian besar dalam kategori pendidikan lanjutan yaitu sebesar $89,1 \%$, sedangkan kategori pendidikan dasar sebesar $10,9 \%$.

Hasil analisis bivariat menunjukkan bahwa uji statistik dengan chi-square diperoleh $p$ value 0,660 dimana $p \geq 0,05$ sehingga secara statistik tidak signifikan maka dapat diketahui bahwa tidak terdapat hubungan antara tingkat pendidikan 
responden dengan perilaku tes HIV. Dari hasil tabulasi silang menunjukkan bahwa responden yang memiliki perilaku tes HIV tergolong baik lebih banyak terdapat pada responden dengan kategori pendidikan lanjutan $(53,1 \%)$ dibandingkan dengan responden dengan kategori pendidikan dasar $(41,7 \%)$. Sedangkan responden yang memiliki perilaku tes HIV tergolong buruk lebih banyak terdapat pada responden dengan kategori pendidikan dasar $(58,3 \%)$ dibandingkan dengan responden dengan kategori pendidikan lanjutan (46,9\%).

Penelitian ini sejalan dengan sebuah penelitian di Afrika Selatan yang menyatakan bahwa responden dengan tingkat pendidikan yang lebih tinggi cenderung memiliki penerimaan yang lebih tinggi terhadap VCT (Johnston, 2008).

Menurut Notoatmojo, semakin tinggi pendidikan, maka semakin mudah menyerap pengetahuan dan semakin mudah pula melakukan praktik sesuai dengan pengetahuan yang didapatkan. Menurut Notoatmojo, pendidikan merupakan upaya yang direncanakan untuk mempengaruhi orang lain, baik individu, kelompok maupun masyarakat. Pendidikan yang lebih tinggi akan lebih banyak menerima informasi sehingga lebih memperhatikan kesehatannya (Notoatmojo, 2007).
Karakteristik Responden Menurut Jenis Tempat Tinggal

Berdasarkan hasil penelitian statistik univariat menunjukkan bahwa jenis tempat tinggal responden sebagian besar dalam kategori tinggal sendiri yaitu sebesar 90,9\%, sedangkan kategori tinggal bersama keluarga sebesar $9,1 \%$.

Hasil analisis bivariat menunjukkan bahwa uji statistik dengan chi-square diperoleh $\mathrm{p}$ value 0,047 dimana $\mathrm{p}<0,05$ sehingga secara statistik signifikan maka dapat diketahui bahwa terdapat hubungan antara tipe tempat tinggal responden dengan perilaku tes HIV. Dari hasil tabulasi silang menunjukkan bahwa responden yang memiliki perilaku tes HIV tergolong baik lebih banyak terdapat pada responden yang tinggal sendiri $(55,0 \%)$ dibandingkan dengan responden yang tinggal bersama keluarga $(20,0 \%)$. Sedangkan responden yang tidak pernah melakukan tes HIV lebih banyak terdapat pada responden yang tinggal bersama keluarga $(80,0 \%)$ dibandingkan dengan responden yang tinggal sendiri $(45,0 \%)$.

Hal ini sejalan dengan sebuah penelitian oleh Rosa Solorio dkk, yang menyatakan bahwa anggota keluarga memiliki sikap negatif terhadap tes HIV. Responden menyatakan bahwa anggota keluarga akan menanyakan pertanyaan mengapa perlu melakukan tes HIV. Dalam hal ini, terjadi bentuk homophobia di 
lingkungan keluarga (Solorio, 2013). Mengenai kondisi di lapangan, responden mengaku lebih nyaman melakukan tes HIV di tempat yang jauh dari keluarga. Hal ini karena HIV masih dianggap sebagai penyakit yang mengerikan, dan orang yang melakukan tes HIV masih diidentikkan sebagai orang yang berperilaku tidak baik.

Pengetahuan Responden Tentang IMS, HIV/AIDS dan Tes HIV

Berdasarkan hasil penelitian statistik univariat menunjukkan bahwa pengetahuan responden Tentang IMS, HIV/AIDS dan IMS sebagian besar dalam kategori rendah yaitu sebesar $51,8 \%$, sedangkan kategori tinggi sebesar 48,2\%. Secara lebih rinci, pengetahuan responden yang rendah tentang IMS dapat ditunjukkan bahwa mayoritas responden $(65,5 \%)$ menjawab jika tujuan utama penggunaan kondom dan pelicin selama melakukan hubungan anal seks adalah untuk menambah kenikmatan/tahan lama. Selain itu, sebesar $48,2 \%$ responden tidak mengetahui bahwa penyakit kelamin dapat disembuhkan dengan minum obat antibiotik sesuai dosis.

Pengetahuan responden yang masih rendah terkait dengan HIV dan AIDS dapat dilihat dari sebesar 18,2\% responden masih menjawab jika menggunakan kondom dengan pelicin hand and body lotion sudah cukup untuk mencegah penularan HIV dan
AIDS. Pengetahuan responden yang masih rendah terkait dengan tes HIV dapat ditunjukkan dari sebanyak 19,1\% responden masih menjawab jika tes HIV hanya boleh dilakukan oleh orang yang melakukan hubungan seks berganti-ganti pasangan.

Hasil analisis bivariat menunjukkan bahwa uji statistik dengan chi-square diperoleh $p$ value 0,692 dimana $p \geq 0,05$ sehingga secara statistik tidak signifikan maka dapat diketahui bahwa tidak terdapat hubungan antara pengetahuan responden mengenai IMS, HIV/AIDS dan tes HIV dengan perilaku tes HIV. Hasil penelitian ini sejalan dengan sebuah penelitian yang menyatakan bahwa pengetahuan mengenai transmisi HIV dari ibu ke janin tidak berhubungan dengan tes HIV pada ibu hamil (Walter, 2001).

$$
\text { Dari hasil tabulasi silang }
$$
menunjukkan bahwa responden yang memiliki perilaku tes HIV tergolong baik lebih banyak terdapat pada responden yang memiliki pengetahuan tinggi $(54,7 \%)$ dibandingkan dengan responden yang memiliki pengetahuan rendah $(49,1 \%)$. Sedangkan responden yang tidak pernah melakukan tes HIV lebih banyak terdapat pada responden dengan pengetahuan rendah (50,9\%) dibandingkan responden dengan pengetahuan tinggi $(45,3 \%)$. 


\section{Riwayat Perilaku Berisiko HIV}

Berdasarkan hasil penelitian statistik univariat menunjukkan bahwa riwayat perilaku berisiko HIV pada responden sebagian besar dalam kategori berisiko tinggi yaitu sebesar $61,8 \%$, sedangkan kategori berisiko rendah sebesar $38,2 \%$.

Hasil analisis bivariat menunjukkan bahwa uji statistik dengan chi-square diperoleh $p$ value 1,000 dimana $p \geq 0,05$ sehingga secara statistik tidak signifikan maka dapat diketahui bahwa tidak terdapat hubungan antara riwayat perilaku berisiko HIV dengan perilaku tes HIV. Hal ini sejalan dengan penelitian Allison J. Ober, dkk yang menyatakan bahwa riwayat perilaku berisiko tidak berhubungan dengan perilaku tes HIV (Ober, 2012). Dari hasil tabulasi silang menunjukkan bahwa responden yang memiliki perilaku tes HIV tergolong baik lebih banyak terdapat pada responden yang memiliki riwayat perilaku berisiko rendah $(52,4 \%)$ dibandingkan dengan responden yang memiliki riwayat perilaku berisiko tinggi (51,5\%). Sedangkan responden yang memiliki perilaku tes HIV tergolong buruk lebih banyak terdapat pada responden dengan riwayat perilaku berisiko tinggi $(48,5 \%)$ dibandingkan responden dengan riwayat perilaku berisiko rendah $(47,6 \%)$. Hal ini dapat disebabkan karena pada penelitian ini, walaupun responden dengan riwayat perilaku berisiko rendah mereka memiliki pengetahuan tinggi tentang HIV AIDS, IMS, dan tes HIV, sehingga kesadaran mereka untuk melakukan tes HIV jadi lebih tinggi. Selain itu, perilaku tes HIV pada responden dengan perilaku berisiko rendah dapat juga disebabkan oleh tingkat pendidikan dimana sebagian besar responden memiliki pendidikan lanjutan.

\section{Riwayat Infeksi Menular Seksual}

Berdasarkan hasil penelitian statistik univariat menunjukkan bahwa sebagian besar responden pernah mengalami infeksi menular seksual (IMS) yaitu: $67,3 \%$, sedangkan responden yang tidak pernah mengalami infeksi menular seksual (IMS) sebesar 32,7\%.

Hasil analisis bivariat menunjukkan bahwa uji statistik dengan chi-square diperoleh $p$ value 0,005 dimana $p<0,05$ sehingga secara statistik signifikan maka dapat diketahui bahwa terdapat hubungan antara riwayat infeksi menular seksual pada responden dengan perilaku tes HIV. Hasil penelitian ini sejalan dengan penelitian yang dilakukan di Beijing yang menyatakan bahwa terdapat hubungan antara riwayat penyakit menular seksual dengan perilaku tes HIV (Choi, 2006).

Dari hasil tabulasi silang menunjukkan bahwa responden yang memiliki perilaku tes HIV tergolong baik lebih banyak terdapat pada responden yang 
tidak pernah mengalami IMS (72,2\%) dibandingkan dengan responden yang pernah mengalami IMS (41,9\%). Sedangkan responden yang memiliki perilaku tes HIV tergolong buruk lebih banyak terdapat pada responden yang pernah mengalami IMS $(58,1 \%)$ dibandingkan responden yang tidak pernah mengalami IMS (27,8\%). Hal ini dapat disebabkan karena pada penelitian ini, walaupun responden tidak pernah mengalami IMS, namun mereka memiliki pengetahuan tinggi tentang HIV AIDS, IMS, dan tes HIV, sehingga kesadaran mereka untuk melakukan tes HIV jadi lebih tinggi. Selain itu, perilaku tes HIV pada responden yang tidak pernah mengalami IMS dapat juga disebabkan oleh tingkat pendidikan dimana sebagian besar responden memiliki pendidikan lanjutan.

Infeksi menular seksual sangat erat kaitannya dengan HIV dan AIDS. Karena IMS dapat mempermudah terinfeksi HIV. sebuah penelitian menyebutkan bahwa riwayat sifilis dan IMS rectal merupakan faktor yang berhubungan dengan kejadian infeksi HIV pada waria di Indonesia (Prabawanti, 2011). Berdasarkan kondisi di lapangan, responden yang melakukan tes HIV biasanya juga melakukan tes IMS karena IMS merupakan pintu masuk terjangkitnya HIV.

Dari analisis multivariat, diketahui bahwa variabel riwayat IMS dengan odds ratio 3,4 (95\% CI: 1,395-8,288), artinya responden yang pernah mengalami IMS memiliki kecenderungan 3,4 kali lebih besar untuk memiliki perilaku tes HIV tergolong baik dibandingkan responden yang tidak pernah mengalami IMS. Hal ini sesuai dengan sebuah penelitian yang dilakukan di China yang menyebutkan bahwa riwayat penyakit menular seksual berpengaruh terhadap perilaku tes HIV pada LSL di Beijing, China (Choi, 2006).

\section{Persepsi Terhadap Kerentanan Tertular HIV dan AIDS}

Berdasarkan hasil penelitian statistik univariat menunjukkan bahwa persepsi responden terhadap kerentanan tertular HIV dan AIDS sebagian besar dalam kategori rendah yaitu sebesar $60,0 \%$, sedangkan kategori tinggi sebesar 40,0\%. Secara lebih rinci, persepsi kerentanan tertular HIV dan AIDS pada responden yang rendah ditunjukkan oleh sebanyak $24,5 \%$ responden masih menganggap bahwa orang yang mudah tertular HIV adalah orang dengan usia lebih dari 40 tahun, karena daya tahan tubuhnya sudah menurun. Selain itu, sebanyak 27,3\% responden tidak merasa tertular HIV karena hanya memiliki satu pasangan seksual. Hal ini sejalan dengan penelitian Abiy Abebe, yang mendapatkan bahwa terdapat 37,3\% responden tidak merasa rentan tertular HIV karena hanya memiliki satu pasangan 
seksual dan mereka sangat percaya pada pasangannya (Abebe, 2009).

Hasil analisis bivariat menunjukkan bahwa uji statistik dengan chi-square diperoleh $p$ value 0,370 dimana $p \geq 0,05$ sehingga secara statistik tidak signifikan maka dapat diketahui bahwa tidak terdapat hubungan antara persepsi responden mengenai kerentanan terinfeksi HIV dan AIDS dengan perilaku tes HIV. hal ini sejalan dengan penelitian di los Angeles yang menyatakan bahwa tidak terdapat hubungan antara persepsi kerentanan responden terhadap perilaku tes HIV (Ober, 2012). Dari hasil tabulasi silang menunjukkan bahwa responden yang memiliki perilaku tes HIV tergolong baik lebih banyak terdapat pada responden yang memiliki persepsi kerentanan rendah $(56,1 \%)$ dibandingkan dengan responden yang memiliki persepsi kerentanan tinggi (45,5\%). Sedangkan responden yang memiliki perilaku tes HIV tergolong buruk lebih banyak terdapat pada responden dengan persepsi kerentanan tinggi $(54,5 \%)$ dibandingkan dengan responden dengan persepsi kerentanan rendah $(43,9 \%)$.

Menurut Rosenstock, et al (1990) dalam Walker (2004), menyatakan bahwa jika persepsi terhadap kerentanan dan Keparahan Terhadap HIV dan AIDS tinggi, maka perilaku untuk melindungi diri sendiri juga tinggi. Sebaliknya, jika persepsi terhadap kerentanan dan Keparahan
Terhadap HIV dan AIDS tergolong rendah, maka perilaku untuk melindungi diri sendiri juga rendah (Walker, 2004). Teori tesebut tidak sejalan dengan hasil penelitian ini karena mayoritas responden yang memiliki perilaku tes HIV tergolong baik justru yang memiliki persepsi terhadap kerentanan yang tergolong rendah. Berdasarkan kondisi di lapangan, sebagian responden merasa setia pada pasangannya dan yakin pasangannya juga setia, namun mereka tetap melakukan tes HIV karena atas kesadaran sendiri maupun diajak oleh sahabat atau penjangkau lapangan.

\section{Persepsi Terhadap Keparahan Terhadap HIV dan AIDS}

Berdasarkan hasil penelitian statistik univariat menunjukkan bahwa persepsi responden terhadap Keparahan Terhadap HIV dan AIDS sebagian besar dalam kategori rendah yaitu sebesar 56,4\%, sedangkan kategori tinggi sebesar 43,6\%. Secara lebih rinci, hal ini ditunjukkan dengan masih ada sebanyak 59,1\% responden yang menyatakan tidak setuju jika pasangan tetapnya berisiko terinfeksi HIV sama parahnya dengan dia, karena berhubungan seksual dengan responden. Selain itu, sebanyak $60 \%$ responden menyatakan tidak setuju jika pasangan seksual tetapnya memiliki risiko yang sama untuk terinfeksi AIDS dibandingkan dengan pasangan tidak tetapnya. 
Hasil analisis bivariat menunjukkan bahwa uji statistik dengan chi-square diperoleh $p$ value 1,000 dimana $p \geq 0,05$ sehingga secara statistik tidak signifikan maka dapat diketahui bahwa tidak terdapat hubungan antara persepsi responden terhadap Keparahan Terhadap HIV dan AIDS dengan perilaku tes HIV. Dari hasil tabulasi silang menunjukkan bahwa responden yang memiliki perilaku tes HIV tergolong baik lebih banyak terdapat pada responden yang memiliki persepsi keparahan tinggi $(52,1 \%)$ dibandingkan dengan responden yang memiliki persepsi keparahan rendah (51,6\%). Sedangkan responden yang memiliki perilaku tes HIV tergolong buruk lebih banyak terdapat pada responden dengan persepsi keparahan rendah $(48,4 \%)$ dibandingkan responden dengan persepsi keparahan tinggi (47,9\%).

Hasil penelitian ini sesuai dengan teori Health Belief Model yang dikemukakan oleh Rosenstock dalam Walker (2004) yang menyatakan jika persepsi terhadap Keparahan Terhadap HIV dan AIDS yang tinggi akan menyebabkan perilaku perlindungan diri juga tinggi. Hal ini sejalan dengan hasil penelitian ini yaitu: responden yang memiliki perilaku tes HIV tergolong tinggi sebagian besar adalah responden dengan persepsi terhadap Keparahan Terhadap HIV dan AIDS yang tergolong tinggi.

\section{Persepsi Terhadap Manfaat Melakukan}

\section{Tes HIV}

Berdasarkan hasil penelitian statistik univariat menunjukkan bahwa persepsi responden terhadap manfaat melakukan tes HIV sebagian besar dalam kategori rendah yaitu sebesar $75,5 \%$, sedangkan kategori tinggi sebesar 24,5\%. Secara lebih rinci, hal ini ditunjukkan dengan sebanyak 40,9\% responden masih menganggap jika hasil tes HIV nya positif (reaktif) maka beban hidupnya akan bertambah sehingga menimbulkan stress. Selain itu, sebesar 27,3\% responden masih menganggap jika hasil tes HIV nya positif (reaktif) maka mereka akan dipaksa untuk mengikuti kelompok dukungan sebaya.

Dari hasil tabulasi silang menunjukkan bahwa responden yang memiliki perilaku tes HIV tergolong baik lebih banyak terdapat pada responden yang memiliki persepsi manfaat tinggi $(51,9 \%)$ dibandingkan dengan responden yang memiliki persepsi manfaat rendah rendah $(51,8 \%)$. Sedangkan responden yang memiliki perilaku tes HIV tergolong buruk lebih banyak terdapat pada responden dengan persepsi manfaat rendah $(48,2 \%)$ dibandingkan dengan responden dengan persepsi manfaat tinggi $(48,1 \%)$.

Hasil analisis bivariat menunjukkan bahwa uji statistik dengan chi-square diperoleh $p$ value 1,000 dimana $p \geq 0,05$ sehingga secara statistik tidak signifikan 
maka dapat diketahui bahwa tidak terdapat hubungan antara persepsi responden terhadap manfaat melakukan tes HIV dengan perilaku tes HIV. Penelitian ini sejalan dengan sebuah penelitian yang menyatakan bahwa tidak terdapat hubungan antara persepsi terhadap manfaat dengan perilaku seksual berisiko HIV (Alan, 1998). Berdasarkan kondisi di lapangan, mayoritas responden melakukan tes HIV karena dijangkau oleh penjangkau lapangan maupun diajak oleh teman, dalam proses penjangkauan, responden dijelaskan mengenai manfaat melakukan tes HIV.

\section{Persepsi Terhadap Hambatan Dalam Mengakses Layanan Tes HIV}

Berdasarkan hasil penelitian statistik univariat menunjukkan bahwa persepsi responden terhadap hambatan dalam mengakses layanan tes HIV sebagian besar dalam kategori tinggi yaitu sebesar $53,6 \%$, sedangkan kategori rendah sebesar 46,4\%. Secara lebih rinci, hal ini dapat dilihat bahwa mayoritas responden $(52,7 \%)$ masih merasa takut apabila setelah melakukan tes HIV maka hasilnya akan positif (reaktif). Sebanyak $21,8 \%$ responden juga menjawab setuju jika jam buka klinik tes HIV bersamaan dengan jadwal kerja, sehingga mereka tidak mempunyai waktu untuk mengaksesnya. Hasil penelitian ini sejalan dengan sebuah penelitian yang menyebutkan bahwa salah satu faktor penghambat dalam melakukan tes HIV pada populasi berisiko tinggi adalah ketakutan akan hasil tes yang reaktif/positif (Awad, 2004). Hasil penelitian ini juga sejalan dengan penelitian oleh Dr. Argyo Demartoto yang menyatakan bahwa keengganan LSL untuk melakukan tes HIV karena adanya perasaan takut akan hasil tes yang positif/reaktif (Demartoto, 2010). Hasil penelitian lain menyebutkan bahwa hambatan responden dalam mengakses layanan VCT di Butajira tergolong tinggi. Hambatan yang tinggi dalam hal pembiayaan dan rasa tidak nyaman ketika akan melakukan tes (Abebe, 2009).

Hasil analisis bivariat menunjukkan bahwa uji statistik dengan chi-square diperoleh $p$ value 0,681 dimana $p \geq 0,05$ sehingga secara statistik tidak signifikan maka dapat diketahui bahwa tidak terdapat hubungan antara persepsi hambatan dalam mengakses layanan tes HIV dengan perilaku tes HIV. Dari hasil tabulasi silang menunjukkan bahwa responden yang memiliki perilaku tes HIV tergolong baik lebih banyak terdapat pada responden yang memiliki persepsi hambatan rendah (54,9\%) dibandingkan dengan responden yang memiliki persepsi hambatan tinggi (49,2\%). Sedangkan responden yang memiliki perilaku tes HIV tergolong buruk lebih banyak terdapat pada responden dengan persepsi hambatan tinggi $(50,8 \%)$ 
dibandingkan responden dengan persepsi hambatan rendah $(45,1 \%)$.

\section{SIMPULAN}

Perilaku tes HIV pada LSL tergolong baik. Mayoritas responden pernah melakukan tes HIV dalam kurun waktu 0-6 bulan yang lalu. Sebagian besar responden melakukan tes HIV terakhir di Kota Denpasar. Bentuk tes HIV yang dilakukan oleh responden seluruhnya adalah Voluntary Counseling and testing (VCT) serta semua responden mengetahui hasil tes HIV nya.

\section{KEPUSTAKAAN}

Abebe, A., Mitikie, G. 2009. Perception of High School Students towards Voluntary HIV Counseling and Testing, using Health Belief Model in Butajira, SNNPR. Ethiop J Health Dev Vol 23.

Alan, J., Crawford, S.L. 1998. The Health Belief Model and HIV Risk Behaviour: A Causal Model Analysis among Anglos, AfricanAmericans and MexicanAmericans. Ethnicity and Health Vol 3.

Andersen. 1995. Revisting the Behavioral Model and Access to Medical Care. University of California Vol 36.

Awad, G.H., Sagrestano, L.M., Kittletson, M.J, et al. 2004. Development of a
Measure of Barriers to HIV Testing Among Individuals at High Risk. AIDS Educational and Prevention Vol 2.

Bwambale, F.M., Sali, S.N., Byaruhanga, S., et al. 2008. Voluntary HIV counselling and testing among men in rural western Uganda: Implications for HIV prevention. BioMed Central Vol 8.

Choi, K.H., Lui, H., Guo, Y., et al. 2006. Lack of HIV Testing and Awareness of HIV Infection Among Men Who Have Sex With Men, Beijing, China. AIDS Education and Prevention Vol 18.

Coulter, A. 2007. Sexual Sensation Seeking and Self-Efficacy's Relationship to Sexual Risk Taking Behavior. New York: Humboldt State University.

Demartoto, A. 2010. Perilaku Laki-Laki Yang Berhubungan Seks Dengan Laki-Laki (LSL) Untuk Melakukan Test HIV di Kota Surakarta. Surakarta: Universitas Sebelas Maret.

Departemen Kesehatan Republik Indonesia. 2007. Surveilans Terpadu-Biologis Perilaku Pada Kelompok Berisiko Tinggi LSL di Indonesia. Jakarta : Depkes RI.

Dinas Kesehatan Provinsi Bali. 2013. Indonesia Response to HIV, Laporan Periode Bulan Oktober 
2013. Denpasar: Dinkes Provinsi Bali.

Johnston, L., O’Bra, H., Chopra, M., et al. 2008. The Associations of Voluntary Counseling and Testing Acceptance and the Perceived Likelihood of Being HIV-Infected Among Men with Multiple Sex Partners in a South African Township. AIDS Behaior Vol 14.

Jones, B. 2010. Capter 4: Health Belief model. New York.

Kementerian Kesehatan Republik Indonesia. 2011. Laporan Surveilans Terpadu Biologis dan Perilaku. Jakarta: Kementerian Kesehatan RI.

Kementerian Kesehatan Republik Indonesia. 2012. Estimasi Populasi Rawan ODHA. Jakarta: Kemenkes RI.

Komisi Penanggulangan AIDS Nasional. 2010a. Strategi dan Rencana Aksi Nasional Penanggulangan HIV dan AIDS Tahun 2010-2014. Jakarta: Komisi Penanggulangan AIDS Nasional.

Komisi Penanggulangan AIDS Nasional. 2010b. Strategi dan Rencana Aksi Nasional Penanggulangan HIV dan AIDS pada Populasi Kunci GWL 2010 - 2014. Jakarta: KPAN.

Lestari, S., Raharjo, M.S. 2012. FaktorFaktor yang Mempengaruhi
Rendahnya Minat LSL di Kota Surakarta untuk Melakukan Tes HIV Secara Sukarela (VCT). Surakarta : Universitas Sebelas Maret.

Mumtaz, G. Are HIV epidemics among men who have sex with men emerging in the Middle East and North Africa?: a systematic review and data synthesis. 2011. PLoS Medicine Vol 8.

Notoatmojo S. 2007. Promosi Kesehatan dan Ilmu Perilaku. Jakarta: Rineka Cipta.

Ober, A.J., Martino, S.C., Ewing, B., et al. 2012. If You Provide The Test, They Will Take It: Factors Associated With HIV/STI Testing in a Representative Sample of Homeless Youth in Los Angeles. AIDS Education and Prevention. The Guilford Press Vol 4.

Solorio, R., Forehand, M., Simoni, J. 2013. Attitudes towards and Beliefs about HIV Testing among Latino Immigrant MSM: A Comparison of Testers and Nontesters. Hindawi Publishing Corporation Vol 23.

Walker, L.J. 2004. Components of The Health Belief Model and HIV Testing Decisions. University of North Carolina, Wilmington.

Walter, E.B., Royce, R.A., Fernandez, M.I., et al. 2001. New Mothers' 
Jurnal Promosi Kesehatan Indonesia Vol. 11 / No. 2 / Agustus 2016

Knowledge and Attitudes About

Perinatal Human

Immunodeficiency Virus infection.

Obstetrics and gynecology. Epub Journal Vol 97.

Wang, Y., Li, B., Pan. J., et al. 2011.

Factors Associated with Utilization

of a Free HIV VCT Clinic by Female

Sex Workers in Jinan City, Northern

China. AIDS Behavior Vol 15.

Yayasan Gaya Dewata. 2011. Laporan

Penjangkauan GWL. Denpasar:

Yayasan Gaya Dewata.

Yayasan Gaya Dewata. 2012. Laporan

Pelaksanaan Kegiatan dan

Keuangan. Denpasar : Yayasan

Gaya Dewata.

Yayasan Gaya Dewata. 2013. Laporan

Pelaksanaan Kegiatan dan

Keuangan. Denpasar : Yayasan

Gaya Dewata.

Yayasan Spirita. 2013. Lembaran Informasi

Tes HIV. Jakarta : Yayasan Spiritia. 